\title{
Albumin metabolism in fasting, obese subjects
}

\author{
By FIONA C. BALLANTYNE,* J. SMITH† AND A. FLECK \\ University Departments of Pathological Biochemistry and \\ Medicine, Royal Infirmary, Castle Street, Glasgow
}

(Received 22 March 1973-Accepted I8 May 1973)

\begin{abstract}
I. Eleven obese subjects fasted for $24 \mathrm{~d}$, by which time their serum albumin concentration had fallen significantly. ${ }^{125}$ I-labelled albumin was injected on day 7 of fasting to allow study of albumin metabolism.

2. Although no significant alteration occurred in either the intravascular content or the absolute catabolic rate of albumin between days 7 and 24 of fasting, the mean values for both content and catabolic rate were significantly lower than values determined in eight normal subjects.

3. A corresponding fall occurred in the absolute 'synthesis + transfer' rate.
\end{abstract}

Fasting is of value in the initial treatment of obesity (Bloom, 1959; Duncan, Jenson, Cristofori \& Schless, 1963 ), although it is not without hazard. For example, metabolic acidosis with ketosis can develop (Bell, Margen \& Calloway, 1969) and excretion of citrate and urate may be impaired (Rapoport, From \& Husdan, 1965). Studies on obese patients ingesting energy-free or low-energy diets show that nitrogen excretion falls dramatically (van Riet, Schwarz \& der Kinderen, I964; Rath \& Masek, I 966 ; Bell et al. 1969), which could imply that little energy is derived from the breakdown of protein.

There have been conflicting reports of the effect of fasting on the serum concentration of proteins in obese subjects. In contrast to the studies of Drenick, Swendseid, Blahd \& Tuttle (1964) and van Riet et al. (1964) in which no alteration was found, the total protein concentration in the serum of three of four patients investigated by Rapoport et al. (1965) rose in the rst week of starvation before falling to base-line concentration or lower by the end of 3 weeks of starvation. The concentration of albumin in serum showed similar, but not identical changes.

In view of the decrease in nitrogen excretion and the conflicting reports of alterations in the concentration of protein in serum, it was decided to study direct the effect of starvation on the metabolism of protein in obese subjects, and albumin was selected for investigation. In normal man and experimental animals, protein deprivation leads to a decrease in the rate of albumin synthesis and, as the plasma content of albumin falls, a compensatory decrease in the rate of albumin catabolism occurs (Hoffenberg, Black \& Brock, I966; James \& Hay, I968; Kirsch, Frith, Black \& Hoffenberg, I968).

* Present address: Department of Biochemistry, Gartnavel General Hospital, Great Western Road, Glasgow.

+ Present address: Medical Division, Gartnavel General Hospital, Great Western Road, Glasgow. 
EXPERIMENTAL

Subjects

Ten female and one male obese subjects (age 22-37 years, mean 29) volunteered to participate in the study. Clinical assessment showed no evidence of any disease, and obesity was attributed solely to overeating. The mean initial body-weight was $103 \mathrm{~kg}$, and over the next 3-4 weeks approximately $14 \%$ of body-weight was lost. The patients were weighed every $4^{\text {th }}$ day and lean body mass was calculated from height and weight (see Hume, I966; Hume \& Weyers, 1971).

Throughout the $3-4$-week period of starvation blood specimens were removed daily without use of anticoagulants, and complete urine collections were made. Samples of serum and urine were stored at $-20^{\circ}$ until analysis. Study of albumin metabolism with ${ }^{125}$ I-labelled albumin was commenced on the $7^{\text {th }}$ day of fasting, since little change was expected before this time. The patients were given KI orally ( $30 \mathrm{mg}$ twice daily) for $2 \mathrm{~d}$ before and throughout the period of ${ }^{125} \mathrm{~T}$-labelled albumin study to minimize thyroidal uptake of ${ }^{125 i o d i d e . ~ E i g h t ~ m e m b e r s ~ o f ~ l a b o r a t o r y ~ s t a f f, ~ w h o s e ~ f o o d ~}$ intake was normal, were also studied to provide a series of normal values for comparison.

\section{Chemical methods}

Serum proteins. Total protein and albumin concentrations were determined in all serum specimens; globulin fractions were measured in every third sample. Total protein was determined by an automated 'biuret' procedure, Technicon AutoAnalyzer method $\mathrm{N}_{4} \mathrm{~B}$ (Technicon Instrument Co. Ltd, Basingstoke, Hants). After electrophoresis on cellulose acetate, albumin and globulin fractions were stained with Ponceau S (G. T. Gurr, London). 'The protein-dye complexes were determined by the elution method of Webster (1965).

Urine nitrogen and creatinine. For urine nitrogen, ammonia was measured by an automated phenol-hypochlorite method using a Technicon AutoAnalyzer (Fleck, I967, I970) after acid digestion of organic nitrogen with $\mathrm{K}_{2} \mathrm{SO}_{4}-\mathrm{HgO}$ at approximately $400^{\circ}$. Urine creatinine was estimated by Technicon AutoAnalyzer method N ir B. After interfering substances have been partly removed by dialysis, creatinine forms a red complex in alkaline picrate solution (Jaffe reaction).

\section{Study of ${ }^{125}$ I-labelled albumin metabolism}

${ }^{125}$ I-labelled human serum albumin prepared by the Radiochemical Centre, Amersham, Bucks., was used. Although designed primarily for measurement of blood volume, a careful evaluation had confirmed that the preparation and handling of the labelled albumin were such that it should be suitable for metabolic use; results obtained for eight members of laboratory staff (Ballantyne, Fleck \& Dick, I97r; Ballantyne \& Fleck, 1973) were in agreement with the accepted normal values of Takeda $\&$ Reeve (I963) and Rossing (1967). Assessment of individual samples of the ${ }^{125} \mathrm{I}$ labelled albumin was also made throughout the period of study. The criteria of acceptability are that a normal subject should excrete less than $5 \%$ of the dose of isotope in the first $24 \mathrm{~h}$ after injection and that throughout a period of several weeks the 
ratio of radioactivity in urine to that in serum should be constant (McFarlane, 1964).

Approximately $25 \mu \mathrm{Ci}{ }^{125} \mathrm{I}$-labelled albumin were injected into an antecubital vein. The contents of the syringe were weighed and, after injection, the residue was washed to a suitable volume with bovine serum albumin ( $2 \mathrm{~g} / \mathrm{l}$; Armour Pharmaceuticals, London) and the ${ }^{125}$ iodide was measured as described below, to determine the exact dose administered. A portion of the ${ }^{125} \mathrm{I}$-labelled albumin was retained to act as a standard. A blood specimen was taken 10 min after injection to allow determination of plasma volume. The activity at $10 \mathrm{~min}$ was multiplied by $1 \cdot 0 \mathrm{I} 5$ to obtain the value at zero time (Hobbs, 1967). Further accurately timed blood specimens were removed at $2 \mathrm{~h}, 6 \mathrm{~h}$ and daily thereafter until the end of the study (about day 24 of fasting). Collection of urine in $24 \mathrm{~h}$ samples was continued throughout this period.

The renal function of the patients was normal and therefore serum could be counted directly without having to isolate the albumin. The ${ }^{125}$ iodide content of duplicate $2 \mathrm{ml}$ samples of serum and urine was measured in a well-type, thalliumactivated, sodium iodide crystal used in conjunction with a pulse height analyser, scaler-timer, automatic turntable and printer supplied by Ekco Electronics, Southendon-Sea. Counting error was less than I $\%$ and efficiency was $43 \%$.

Since the protein metabolism of the subjects could not be assumed to be in 'steady state', the choice of methods for analysis of the tracer results was rather restricted. Changes in plasma volume, initially measured to min after injection of ${ }^{125}$ I-labelled albumin, were calculated from serial measurements of packed cell volume i.e. a constant red cell volume was assumed.

It is customary to express catabolism in terms of both the absolute rate and the fractional rate, where absolute catabolic rate is the mass of albumin catabolized per unit time and fractional catabolic rate is the fraction of the intravascular albumin pool catabolized per unit time. The ratio of urine radioactivity to mid-time serum specific radioactivity was used to calculate the absolute catabolic rate on each day, as described by Campbell, Cuthbertson, Matthews \& McFarlane (1956). This is valid even in the non-'steady-state', whereas use of the corresponding ratio for calculation of fractional rate is valid only if 'steady-state' conditions can be assumed to exist (Matthews, I96r). Total body radioactivity was calculated by subtracting the cumulative excretion of radioactivity in urine from the dose injected, and extravascular radioactivity was calculated by subtracting the plasma radioactivity from the total body radioactivity. The daily ratio of extravascular to intravascular radioactivity was calculated and a mean value for 'synthesis + transfer' rate, where 'transfer' refers to net movement of the protein from the extravascular to the intravascular pool, was also derived from the disappearance of ${ }^{125} \mathrm{I}$-labelled albumin (see Matthews, $196 \mathrm{I}$ ).

\section{RESULTS}

The weight loss of the subjects is shown in Table $\mathrm{I}$; subjects $\mathrm{I}-\mathrm{Io}$ were female and subject I I was male. The characteristic, progressive decrease in nitrogen excretion with time of starvation is given in Fig. $x$. Although it is impossible to exclude occasional 


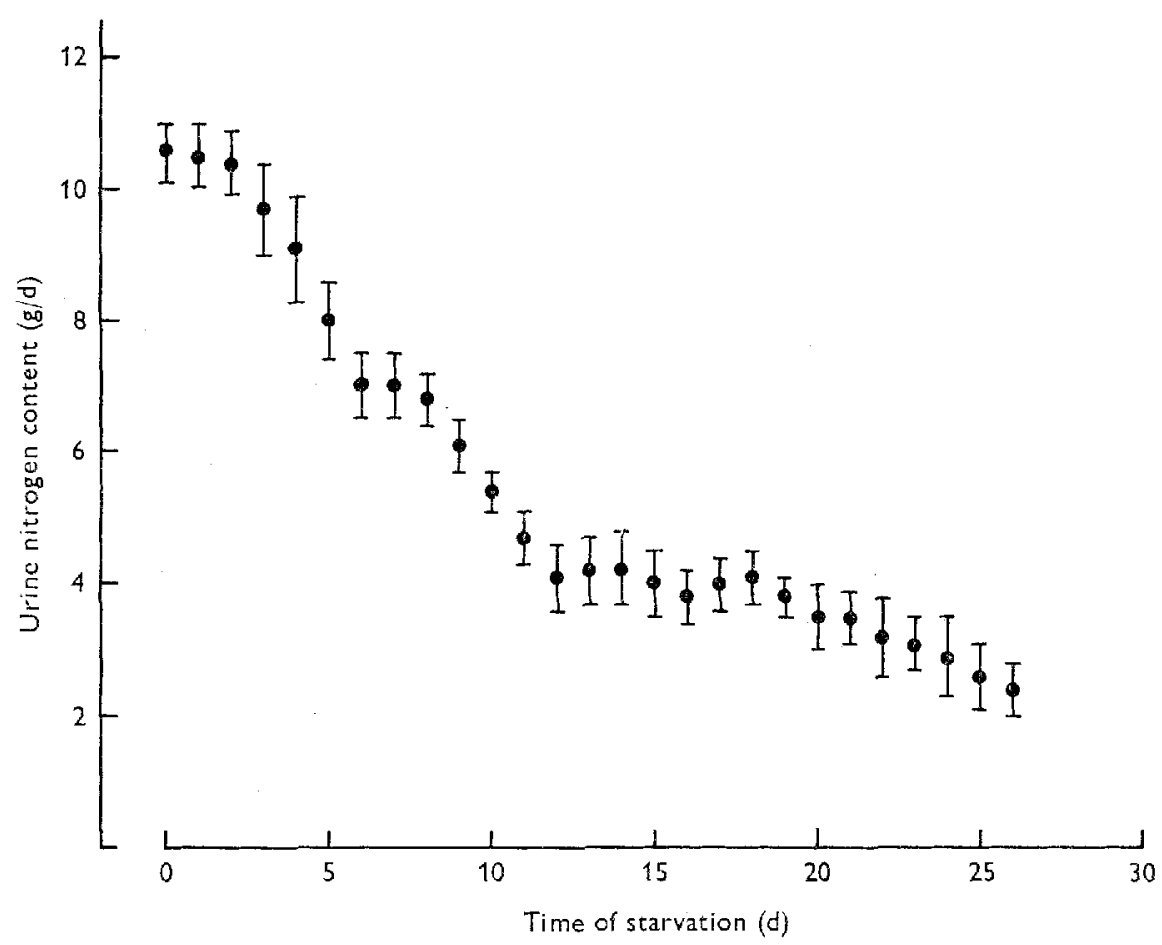

Fig. 1. Nitrogen excreted in urine by the obese subjects with time of fasting. Each result (๑) is the mean value for the eleven subjects and the vertical bars represent the standard errors of the mean. The normal range is $10-15 \mathrm{~g} / \mathrm{d}$.

lapses by patients, these values indicate that the patients generally co-operated in the study. No significant change was found in creatinine excretion during the $3-4$ weeks of the investigation.

In most patients there was greater day-to-day variation in the concentration of serum proteins than has been found in other groups of subjects investigated. This was probably due partly to the difficulty of removing blood from obese subjects. It was sometimes necessary to use stasis, which can alter the relative composition of blood specimens. Some concentration fluctuations can also be ascribed to variation in fluid retention by the obese subjects. Estimates of plasma volume, made by correcting the plasma volume measured on day 7 for changes in packed cell volume, varied throughout the period of study, but no consistent change was found.

Throughout the period of study there was a limited trend towards decrease in the concentration of albumin in serum. As shown in Table 2, the difference in the mean concentrations of albumin between day 2 and day 22 of starvation was significant, whereas the difference between the concentrations on day 2 and on day 7 (when the albumin catabolism study was started) was not significant. Similarly, the values on day 7 and day 22 were not significantly different. No significant change was found in the serum concentration of total protein or globulin fractions. Mean values for the concentrations of the serum proteins during the period of ${ }^{125}$ I-labelled albumin study are given in Table 3 . 
Table I. Weight characteristics in eleven obese subjects during a 4-week period of fasting

\begin{tabular}{|c|c|c|c|c|c|}
\hline $\begin{array}{l}\text { Subject } \\
\text { no. }\end{array}$ & $\begin{array}{c}\text { Age } \\
\text { (years) }\end{array}$ & $\begin{array}{c}\text { Initial } \\
\text { weight (kg) }\end{array}$ & $\begin{array}{l}\text { Weight loss } \\
(4 \text { weeks) (kg) }\end{array}$ & $\begin{array}{l}\text { Woight* } \\
\text { (kg) }\end{array}$ & $\begin{array}{c}\text { Lean body mass* } \\
\text { (kg) }\end{array}$ \\
\hline I & 30 & $94 \cdot 3$ & 17.7 & $84 \cdot 6$ & $46 \cdot 5$ \\
\hline 2 & 24 & II $8 \cdot 4$ & $6 \cdot 8$ & $106 \cdot 4$ & $52 \cdot 9$ \\
\hline 3 & 37 & 127.0 & $24^{\circ} 0$ & I $18 \cdot 2$ & $57^{\circ} 5$ \\
\hline 4 & 22 & 943 & 19.5 & $89 \cdot 1$ & $52 \cdot 6$ \\
\hline 5 & 24 & $88 \cdot 9$ & 104 & $83 \cdot 9$ & 447 \\
\hline 6 & $3 \mathrm{I}$ & ro8.0 & 99 & 104.6 & 53.5 \\
\hline 7 & 33 & $93 \cdot 9$ & $9^{\circ}$ & 894 & $52 \cdot 2$ \\
\hline 8 & 25 & $78 \cdot 0$ & 10.7 & $74 \cdot 8$ & $42 \cdot 4$ \\
\hline 9 & 36 & 90.0 & $11 \cdot 7$ & $84 \cdot 6$ & $5 \mathrm{I} \cdot 8$ \\
\hline Io & 54 & 85.0 & $6 \cdot 5$ & $8 r \cdot 6$ & $42 \cdot 5$ \\
\hline I I & 30 & $x_{53}{ }^{\circ}$ & $25^{\circ} 0$ & I $39^{\circ} \circ$ & $59 \cdot 7$ \\
\hline Mean \pm SEM & $3 I$ & I0 $2 \cdot 8 \pm 6 \cdot 7$ & $13.7 \pm 2.0$ & $96 \cdot 0 \pm 5 \cdot 8$ & $50.6 \pm 1.8$ \\
\hline
\end{tabular}

* Mean value for period during which albumin catabolism was studied with ${ }^{195}$ I-labelled albumin (usually days $7-24$ of fasting).

Table 2. Serum albumin concentration of eleven obese subjects with time of fasting

(Mean values with their standard errors)

$\begin{array}{cc}\text { Day of } & \text { Serum albumin concentration } \\ \text { fasting } & (\mathrm{g} / \mathrm{l}) \\ 2 & 43 \cdot 6 \pm \mathrm{r} \cdot 2 \\ 7 & 40 \cdot 6 \pm 0 \cdot 8 \\ \mathbf{2 2} & 38 \cdot 5 \pm \mathrm{r} \cdot 3\end{array}$

Significance of differences (evaluated by Student's $t$ test)

$\begin{array}{llll}\text { Group (day) } \ldots & 2 v .7 & 7 v .22 & 2 v .22\end{array}$

Difference ... Not significant Not significant $0.01>P>0.005$

Table 3. Serum protein concentrations in eleven fasting, obese subjects

\begin{tabular}{lcc} 
Protein & \multicolumn{2}{c}{ Serum concentration $(\mathrm{g} / \mathrm{l})$} \\
\cline { 2 - 3 } fraction & Mean & SEM \\
Total & 70 & $\mathrm{I} \cdot 3$ \\
Albumin & 39 & $0 \cdot 2$ \\
$\alpha_{1}$-globulin & $3 \cdot 0$ & $0 \cdot 2$ \\
$\alpha_{2}$-globulin & $6 \cdot 9$ & $0 \cdot 4$ \\
$\beta$-globulin & $8 \cdot 1$ & 0.4 \\
$\gamma$-globulin & $12 \cdot 6$ & $1 \cdot 0$
\end{tabular}

On average, albumin catabolism was studied with ${ }^{125}$ I-labelled albumin between days 7 and 24 of fasting.

Plasma albumin expressed as intravascular content showed the same pattern with time of fasting as when expressed as concentration, i.e. there was an overall fall, but no consistent change during the period of ${ }^{125}$ I-labelled albumin study (days $7-24$ ). However, the mean value during the period was significantly lower than in the normal subjects (Table 4.) Similarly, although no significant alteration occurred in the absolute catabolic rate during this time, the mean value was lower than in the normal subjects 
Table 4. Mean values with their standard errors for albumin content and metabolic rates in eleven fasting, obese subjects, and in eight normal subjects

\begin{tabular}{|c|c|c|c|}
\hline \multirow{3}{*}{ Intravenous albumin content } & \multicolumn{3}{|c|}{ Subjects } \\
\hline & $\begin{array}{l}\text { Fasting, } \\
\text { obese }\end{array}$ & Normal & $t$ test \\
\hline & & & \\
\hline $\begin{array}{l}\mathrm{g} \\
\mathrm{g} / \mathrm{kg} \mathrm{LBM}\end{array}$ & $\begin{array}{c}89 \pm 4 \\
x \cdot 76 \pm 0.08\end{array}$ & $\begin{array}{l}112 \pm 6 \\
2 \cdot 42 \pm 0 \cdot 11\end{array}$ & $\begin{array}{c}0.005>P>0.001 \\
P<0.001\end{array}$ \\
\hline $\begin{array}{l}\text { Ratio, extravascular: intravascular } \\
\text { radioactivity }\end{array}$ & $I^{-7} 72 \pm 0 \cdot 10$ & $I \cdot 36 \pm 0.09$ & $0.025>P>0.01$ \\
\hline $\begin{array}{l}\text { Catabolic rate } \\
\text { g/d } \\
\text { g/kg LBM* per d }\end{array}$ & $\begin{array}{l}9.3 \pm 0.5 \\
0.185 \pm 0.010\end{array}$ & $\begin{array}{c}10.6 \pm 0.3 \\
0.229 \pm 0.008\end{array}$ & $\begin{array}{l}0.025>P>0.01 \\
0.005>P>0.001\end{array}$ \\
\hline $\begin{array}{l}\text { 'Synthesis + transfer' rate } \\
\text { g/d } \\
\text { g/kg LBM* per d }\end{array}$ & $\begin{array}{c}9 \cdot 3 \pm 0.4 \\
0.185 \pm 0.008\end{array}$ & $\begin{array}{c}10.6 \pm 0.3 \\
0.229 \pm 0.008\end{array}$ & $\begin{array}{c}0.01>P 0.005 \\
0.005>P>0.001\end{array}$ \\
\hline
\end{tabular}

and a corresponding decrease was found in the absolute 'synthesis + transfer' rate. These measurements of albumin metabolism are also expressed relative to lean body mass in Table 4 and similar conclusions are reached.

No consistent change was found in the ratio of extravascular to intravascular radioactivity in the fasting, obese subjects, but the ratio was significantly higher than in the normal subjects. The mean value is included in Table 4.

\section{DISCUSSION}

The progressive decrease in nitrogen excreted by these fasting, obese subjects is in agreement with the findings of van Riet et al. (1964) and Rath \& Masek (1966). Creatinine excretion did not change significantly, in contrast to the report of Peters, Grosser \& Knapp (1972) that it decreases continuously in fasting, obese women. The finding of a limited fall in the serum albumin concentration and variability in protein concentrations is in agreement with the results of Rapoport et al. (1965).

It would have been preferable to compare results for albumin content and catabolic rate in the fasting, obese subjects with their corresponding values before fasting commenced. However, it was not possible to conduct this study before the subjects were admitted to hospital, and it was not feasible to conduct this study of at least I week's duration after admission - it could not be justified clinically, patients were unwilling to co-operate, and it would have been difficult to provide a diet mimicking their customary excessive food intake. In comparing the groups of obese and normal subjects, lean body mass (Hume, I966; Hume \& Weyers, I97I) was used as reference rather than body-weight as is conventionally done, because of the marked difference in body-weight between the control and obese groups. Although there may be reservations about the general applicability of a calculated value for lean body mass, studies on obese and normal subjects by Hume \& Weyers (I97 I) show that predicted values 
for total body water and therefore lean body mass are applicable up to at least $180 \%$ of the accepted average weight for a given height.

It is somewhat unexpected that, although the intravascular content and the absolute catabolic rate of albumin were lower than those of the control group, no significant change was found in either, during the period in which albumin catabolism was studied. However, no change occurred in these measurements in normal man within each week of a 3- to 6-week study by Hoffenberg et al. ( 1966 ) of experimental protein depletion during which a low-protein ( $\mathrm{log} / \mathrm{d}$ ) diet was ingested. Although the ratio of extravascular to intravascular radioactivity was consistently increased during the period of study, this cannot be equated with the ratio of albumin in these two 'compartments' because of non-'steady-state' conditions. However, it seems likely that the ratio reflects mainly the decreased intravascular content of albumin.

The closeness of agreement between the decreased absolute 'synthesis + transfer' and catabolic rates indicates that there was little net transfer of albumin from the extravascular to the intravascular pool. It cannot, however, be assumed that near 'steady-state' conditions existed, since the design of the investigation makes unstable conditions possible. An analog computer can be used to separate the two factors of synthesis and transfer in the non-'steady-state'; in the 'steady-state', such as in the control subjects, there is no net transfer of the protein from the extravascular to the intravascular pool. Using the programme of Matthews (I965), it has been shown by James \& Hay (1968) that in malnourished children the synthetic rate responds rapidly to a change in protein intake and that transfer of albumin from the extravascular to the intravascular pool is an additional compensation, which diminishes once the catabolic rate falls. This was also found by Kirsch et al. (1968) in studies on rats in which the synthetic rate of albumin was measured by the technique of McFarlane, Irons, Koj \& Regoeczi (1965) from the incorporation of ${ }^{14} \mathrm{C}$ from intravenously injected $\mathrm{Na}_{2}{ }^{14} \mathrm{CO}_{3}$.

It is tempting to speculate that much of the decrease in the absolute rates of 'synthesis + transfer' and of catabolism of albumin occurred during the Ist week of starvation, before the subjects began to selectively catabolize their excess fat. A preliminary report (Runcie, 1971) of the excretion of nitrogen and potassium in obese subjects undergoing prolonged starvation gives a similar suggestion - that protein catabolism is marked only in the first Io $\mathrm{d}$ of fasting. In retrospect, it would have been better to inject ${ }^{125}$ I-labelled albumin at the beginning of starvation to investigate this possibility.

Fasting is now a recognized procedure in the initial treatment of obesity (Runcie $\&$ Thomson, 1970). It is not without hazard, but the morbidity of this therapy is acceptable in comparison with the morbidity of uncontrolled obesity. Although in this investigation changes have been found which possibly occurred in the early stage of starvation, albumin metabolism remained fairly constant in the and and $3^{\text {rd }}$ weeks of starvation. It would be interesting to compare these results with those of patients after long-term fasting, when most of the body fat had been depleted.

We are grateful to the patients for co-operating in this study. The financial support of the Medical Research Council (grant G $968 / 299 / \mathrm{C}$ ) is also acknowledged. 


\section{REFERENCES}

Ballantyne, F. C. \& Fleck, A. (r973). F. clin. Path. (In the Press.)

Ballantyne, F. C., Fleck, A. \& Dick, W. C. (1971). Anm. rheum. Dis. 30, 265.

Bell, J. D., Margen, S. \& Calloway, D. H. (1969). Metabolism ז8, I93.

Bloom, W. L. (1959). Metabolism 8, 2 I4.

Campbell, R. M., Cuthbertson, D. P., Matthews, C. M. E. \& McFarlane, A. S. (1956). Int. F. appl. Radiat. Isotopes $\mathbf{I}, 66$.

Drenick, E. J., Swendseid, M. E., Blahd, W. H. \& Tuttle, S. G. (1964). \%. Am. med. Ass. 187, 100.

Duncan, G. G., Jenson, W. K., Cristofori, F. C. \& Schless, G. L. (1963). Am. F. med. Sci. 245, 515.

Fleck, A. (1967). Proc. Ass. clin. Biochem. 4, 212.

Fleck, A. (r97o). Proc. Nutr. Soc. 29, 8r.

Hobbs, J. T. (1967). Total Blood Volume - Its Measurement and Significance. Amersharn: Radiochemical Centre.

Hoffenberg, R., Black, E. \& Brock, J. F. (1966). F. clin. Invest. 45, I 43.

Hume, R. ( Ig66). F. clin. Path. 19, 389 .

Hume, R. \& Weycrs, E. (1971). F. clin. Path. 24, 234.

James, W. P. T. \& Hay, A. M. (1968). F. clin. Invest. 47, I958.

Kirsch, R., Frith, L., Black, E. \& Hoffenberg, R. (I968). Nature, Lond. 2I7, 578.

McFarlane, A. S. (1964). In Mammalian Protein Metabolism Vol. I, p. 297 [H. N. Munro and J. B. Allison, editors]. New York and London: Academic Press.

McFarlane, A. S., Irons, L., Koj, A. \& Regoeczi, E. (Ig65). Biochem. 7. 95, 536.

Matthews, C. M. E. (1961). F. clin. Invest. 40, 603.

Matthews, C. M. E. (1965). In Radioaktive Isotope in Klinik und Forschung Vol. 4, p. 240 [K. Fellinger and R. Höfer, editors]. Munich: Urban and Schwarzenberg.

Peters, W.-H., Grosser, V. \& Knapp, A. (1972). Clinica chim. Acta 39, 273.

Rapoport, A., From, G. L. A. \& Husdan, H. (1965). Metabolism 14, 47.

Rath, R. \& Masek, J. (1966). Metabolism 15, I.

Rossing, N. (1967). Clin. Sci. 33, 593.

Runcie, J. (1971). Scott. med. Ұ. 16, 339.

Runcie, J. \& Thomson, T. J. (1970). Br. med. J. iii, 432.

Takeda, Y. \& Reeve, E. B. (1963). F. Lab. clin. Med. 6r, 183.

van Riet, H. G., Schwarz, F. \& der Kinderen, P. J. (1964). Metabolism r3, 29 I.

Webster, D. (1965). Clinica chim. Acta rr, roI. 